\title{
Effect of Supplementation with Moringa Leaves Powder (MLP) and Fermentation on Chemical Composition, Total Minerals Contents and Sensory Characteristics of Sorghum Flour
}

\author{
Azhari A. Mohammed Nour ${ }^{1}$, Mohamed A. E. M. Ibrahim² \\ ${ }^{1}$ Department of Nutrition and Food Technology, Faculty of Science and Technology, Omdurman Islamic University, Omdurman, Sudan, \\ Now, Albaha University, FAMS, Albaha City, Saudi Arabia KSA \\ ${ }^{2}$ Faculty of Public and Environmental Health, University of Khartoum, Sudan, Now, Albaha University, FAMS, Albaha City, Saudi Arabia \\ KSA
}

Subject Area: Nutrition Science

Corresponding Author: Azhari .A.M Nour

Email: azhari1933@gmail.com- azharinoor@hotmail.com

\begin{abstract}
Sorghum flour was supplemented with different levels (5, 10 and 15\%) of Moringa Leaves Powder (MLP). The effect of supplementation on proximate composition, minerals contents and sensory characteristics was investigated. Supplementation of sorghum flour with different levels of (MLP) increased the proximate composition except the carbohydrate content, moreover supplementation of sorghum flour with MLP slightly decreased the oil content and significantly $(P \leq 0.05)$ decreased the total energy.

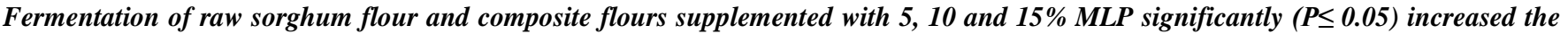
protein content. Moreover the ash, oil and moisture content of raw sorghum flour and supplemented flours with $5 \%$ and $15 \%$ MLP were increased after fermentation.
\end{abstract}

Keywords: Supplementation; Sensory characteristics; Fermentation; Moringa; proximate composition; Minerals

\section{Introduction}

Among the plant foods, cereals are grown over $73.5 \%$ of the world harvested area. Diets in developing countries are based mainly on cereals and legumes. Sorghum is the fifth most important world cereal, following wheat, maize, rice and barely (Onwume and Sinha (1991). Sorghum is cultivated in many parts of the Sudan mainly in Gezira and Gadarief Regions. According to the Ministry of Agriculture (1995) the annual production of sorghum is about 3.7 million tons in Sudan while the area under cultivation ranged from 6.5 to 15.3 million feddans. Sorghum generally consumed as fermented flat bread (Kisra), thick Porridge (Aceda), thin fermented gruel (Nasha), boiled grain (Balela) and beverages like Abreshand Hulu-mur. It is also used for the production of alcoholic beverage (merisa). Grain sorghum as a staple food is also used as feed for animal and as industrial raw material. . Sorghum like other cereals is deficient in lysine (El Tinay et al., 1985). Sorghum Proximate composition varies significantly due to genetics and environment (Ralph, et al., 2000). Sorghum grains contain low quality protein and considerable amounts of antinutritional factors. Efforts, however, are directed to improve the nutritional value of the seeds. Processing method, such as soaking, sprouting and cooking has been found to improve the nutritional value of plant grains (Jirapaet al., 2001). Fermentation is found to be highly beneficial in improving the quality of cereals, it is one of oldest and most economical methods that provide away to preserve food, destroy undesirable factors enhance nutritive value, and improve appearance and taste of some foods. Moringa oleifera leaves as rich in protein source, which can be used by doctors, nutritionists and community health cautious persons to solve worldwide malnutrition or under nutrition problems Thurber and Fahey, (2009). Some articles and research studies have reported that the dry leaves of $M$. oleifera contain 7 times more vitamin C than orange, 10 times vitamin A than carrot, 17 times calcium than milk, 15 times potassium than bananas, 25 times iron than spinach and 9 times proteins than yogurt (Fuglie, 1999). Apart from the medicinal uses, Moringa oleifera was reported to be a good source of vitamins and amino acids (Olugbemiet al;2010). M. oleifera is a miracle tree with a great indigenous source of highly digestible proteins, $\mathrm{Ca}, \mathrm{Fe}$ and Vitamin C. It contains all the essential nutritional elements that are essential for livestock and human beings (Fahey, 2005).

Recently, researchers have become convinced that nutrients found in fruits and vegetables do more than just prevent deficiency diseases for instance beriberi or rickets. The most publicized findings reveals that certain Vitamin or Vitamins precursors in produce, notably Vitamin C; beta carotene as well as polyphenols are powerful anti oxidants which are helpful in the prevention of muscular damage caused by oxidation process of some food substances that could lead to muscle degeneration, cardio vascular disease and cancer (Yonkers 1988 and Islam et,al 2002).

The objective of this study would to evaluate the effect of supplementation with Moringa leaves and fermentation on proximate composition, total minerals ( $\mathrm{K}, \mathrm{Na}, \mathrm{Mg}$ and $\mathrm{Fe}$ ) and sensory characteristics of sorghum (Tabat) flour. 


\section{International Journal of Science and Research (IJSR) \\ ISSN (Online): 2319-7064 \\ Index Copernicus Value (2013): 6.14 | Impact Factor (2014): 5.611}

\section{Materials and Methods}

\section{Source of Materials}

Sorghum (sorghum bicolor L. Moench) grains locally known as Tabat was purchased from Omdurman local market, Sudan. The grains were cleaned and freed from foreign materials. Some of these grains were milled into flour ( $0.4 \mathrm{~mm}$ screen) and stored at $4 \mathrm{C}^{0}$. Moringa leaves obtained from the farm of Alsamrab , Khartoum North, Sudan. The leaves were dried under optimum condition, then milled into powder $\left(0.4 \mathrm{~mm}\right.$ screen) and stored at $4 \mathrm{C}^{0}$.

\section{Supplementation}

Moringa leaves powder were added using Pearson square to increase nutritive value of sorghum flour by 5, 10 and 15\%. The number of samples of composite flour after supplementation were three samples.

\section{Fermentation:}

Natural fermentation of sorghum flour and was carried out by mixing flour with distilled water $(1: 2 \mathrm{w} / \mathrm{v})$. Two hundred and fifty grams of sample was mixed with $500 \mathrm{ml}$ distilled water in $750 \mathrm{ml}$ beaker and then incubated (Gallenkamp, England) at $37^{\circ} \mathrm{C}$ for $24 \mathrm{~h}$. After the incubation period the sample was mixed using a glass rod and transferred to aluminum dishe (30 $\mathrm{cm}$ diameter), and dried in a hot air oven at $70^{\circ} \mathrm{C}$ for $3-4$ hours. Dried sample was ground using

house blender and mortar to pass through $0.4 \mathrm{~mm}$ screen and stored at $4^{\circ} \mathrm{C}$ for further analysis.

\section{Proximate analysis}

Lipid, ash, total carbohydrate and total nitrogen (microKjeldahl) of sorghum flour were determined according to AOAC (1990). Protein was calculated as N\% $\times 6.25$. Moisture content was determined by drying a sample at 105 $\mathrm{C}^{0}$ overnight. Crude fiber content was determined according to the acid/alkali digestion method of Southgate (1976). The energy values of samples were calculated on Atwater factors (Sukkar, 1985), protein (4kcal g $\left.{ }^{-1}\right)$, oil $\left(9 \mathrm{kcal} \mathrm{g}^{-1}\right)$ and carbohydrates $\left(4 \mathrm{kcal}^{-1}\right)$.

\section{Total minerals}

Minerals were determined in samples extracts prepared by the dry- ashing method as described by Pearson (1981) according to the analytical method of atomic absorption spectroscopy (Perkin-Elmer $1100 \mathrm{~V}$, Waltham. MA, USA).

\section{Statistical analysis}

Replicate of each sample was analyzed using statistical system, the analysis of variance was performed to examine the significant effect in all parameters, Least Significant Difference test (LSD test), was used to separate the means (Peterson, 1985).

\section{Results and Discussion}

Table 1: proximate composition and total energy of sorghum flour (Tabat) and Moringa leaves

\begin{tabular}{|c|c|c|c|c|c|c|c|}
\hline Samples & $\begin{array}{c}\text { Moisture } \\
\%\end{array}$ & $\begin{array}{c}\text { Ash } \\
\%\end{array}$ & $\begin{array}{c}\text { Protein } \\
\%\end{array}$ & $\begin{array}{c}\text { Oil } \\
\%\end{array}$ & $\begin{array}{c}\text { Fiber } \\
\%\end{array}$ & $\begin{array}{c}\text { Carbohydrate } \\
\%\end{array}$ & Total energy (kcal) \\
\hline Moringa leaves & 7.36 & 11.93 & 26.71 & 4.94 & 11.16 & 54.46 & 369.13 \\
\hline Sorghum & 7.35 & 1.32 & 10.31 & 2.85 & 2.43 & 75.74 & 369.86 \\
\hline
\end{tabular}

*Each value in the Table is a mean of three replicates \pm S.D

The proximate composition and total energy of raw sorghum flour and composite flour supplemented with Moringa Leaves Powder (MLP) are presented in Table 1. The moisture, ash, protein, oil, fiber, carbohydrate and total energy of MLP were found to be 7.36, 11.93, 26.71, 4.94, 11.16, 54.46 and 369.13\%, respectively. All these parameters were higher than those reported by Bolaji et al ,
(2013) except the protein, who reported that the proximate composition of Moringa leaves (moisture, ash, fat, fiber, protein and total carbohydrate ) were 9.00, 6.00, 2.43, 5.43, 39.13 and $38.21 \%$, respectively. The variation in proximate composition in this study and other comparable study may be due to genotypes, genetic factor and environmental conditions.

Table 2: Effect of supplementation with different levels of Moringa leaves and fermentation on proximate composition and total energy of sorghum flour

\begin{tabular}{|c|c|c|c|c|c|c|c|c|}
\hline $\begin{array}{c}\text { Supplementation } \\
\text { Levels (\%) }\end{array}$ & Treatment & $\begin{array}{c}\text { Moisture } \\
\text { Content (\%) }\end{array}$ & $\begin{array}{c}\text { Ash content } \\
(\%)\end{array}$ & $\begin{array}{c}\text { Crude } \\
\text { protein }(\%)\end{array}$ & $\begin{array}{c}\text { Oil content } \\
(\%)\end{array}$ & $\begin{array}{c}\text { Crude fibre } \\
\text { (\%) }\end{array}$ & $\begin{array}{c}\text { Carbohydrate } \\
(\%)\end{array}$ & $\begin{array}{l}\text { Total energy } \\
\text { (kcal) }\end{array}$ \\
\hline \multirow[t]{2}{*}{0} & Raw & $\begin{array}{l}7.35^{c} \\
( \pm .07)\end{array}$ & $\begin{array}{c}1.32^{\mathrm{C}} \\
( \pm 0.08)\end{array}$ & $\begin{array}{c}10.31^{\mathrm{h}} \\
( \pm 0.01)\end{array}$ & $\begin{array}{c}2.85^{\mathrm{c}} \\
( \pm 0.09)\end{array}$ & $\begin{array}{c}2.43^{\mathrm{d}} \\
( \pm 0.08)\end{array}$ & $\begin{array}{l}75.74^{\mathrm{a}} \\
( \pm 0.32)\end{array}$ & $\begin{array}{l}369.86^{\mathrm{a}} \\
( \pm 0.41)\end{array}$ \\
\hline & Fermented & $\begin{array}{c}6.29^{\mathrm{e}} \\
( \pm 0.08)\end{array}$ & $\begin{array}{c}1.43^{\mathrm{c}} \\
( \pm 0.01)\end{array}$ & $\begin{array}{l}12.38^{f} \\
( \pm 0.4)\end{array}$ & $\begin{array}{c}2.36^{\mathrm{c}} \\
( \pm 0.05)\end{array}$ & $\begin{array}{c}2.40^{\mathrm{d}} \\
( \pm 0.59)\end{array}$ & $\begin{array}{c}75.21^{\mathrm{a}} \\
( \pm 0.11)\end{array}$ & $\begin{array}{l}364.49^{\mathrm{b}} \\
( \pm 0.29)\end{array}$ \\
\hline \multirow[t]{2}{*}{5} & Raw & $\begin{array}{l}8.11^{b} \\
( \pm .07)\end{array}$ & $\begin{array}{c}1.86^{\mathrm{C}} \\
( \pm 0.03)\end{array}$ & $\begin{array}{l}11.87^{\mathrm{g}} \\
( \pm 0.08)\end{array}$ & $\begin{array}{c}2.65^{\mathrm{c}} \\
( \pm 0.44)\end{array}$ & $\begin{array}{c}2.64^{\mathrm{d}} \\
( \pm 0.05)\end{array}$ & $\begin{array}{l}72.54^{b} \\
( \pm 0.08)\end{array}$ & $\begin{array}{l}358.99^{c} \\
( \pm 2.34)\end{array}$ \\
\hline & Fermented & $\begin{array}{l}6.58^{\mathrm{d}} \\
( \pm .15)\end{array}$ & $\begin{array}{c}1.76^{\mathrm{c}} \\
( \pm 0.04)\end{array}$ & $\begin{array}{l}13.32^{d} \\
( \pm 0.07)\end{array}$ & $\begin{array}{c}2.81^{\mathrm{c}} \\
( \pm 0.07)\end{array}$ & $\begin{array}{c}2.63^{\mathrm{d}} \\
( \pm 0.13)\end{array}$ & $\begin{array}{l}72.53^{\mathrm{b}} \\
( \pm 0.15)\end{array}$ & $\begin{array}{l}356.90^{\mathrm{d}} \\
( \pm 0.49)\end{array}$ \\
\hline \multirow[t]{2}{*}{10} & Raw & $\begin{array}{c}8.39^{\mathrm{a}} \\
( \pm 0 . .07)\end{array}$ & $\begin{array}{c}3.36^{\mathrm{b}} \\
( \pm 0.69)\end{array}$ & $\begin{array}{c}12.89^{\mathrm{e}} \\
( \pm 0.09)\end{array}$ & $\begin{array}{c}3.75^{b} \\
( \pm 0.13) \\
\end{array}$ & $\begin{array}{c}3.19^{c} \\
( \pm 0.02)\end{array}$ & $\begin{array}{l}68.41^{\mathrm{C}} \\
( \pm 0.9)\end{array}$ & $\begin{array}{l}371.37^{\mathrm{e}} \\
( \pm 0.85)\end{array}$ \\
\hline & Fermented & $\begin{array}{c}7.50^{\mathrm{c}} \\
( \pm 0.26)\end{array}$ & $\begin{array}{c}2.94^{\mathrm{b}} \\
( \pm 0.16)\end{array}$ & $\begin{array}{l}14.83^{\mathrm{b}} \\
( \pm 0.06)\end{array}$ & $\begin{array}{c}3.68^{\mathrm{b}} \\
( \pm 0.04)\end{array}$ & $\begin{array}{c}3.15^{\mathrm{c}} \\
( \pm 0.12)\end{array}$ & $\begin{array}{l}67.39^{\mathrm{d}} \\
( \pm 0.15)\end{array}$ & $\begin{array}{l}370.09^{\mathrm{e}} \\
( \pm 0.19)\end{array}$ \\
\hline \multirow[t]{2}{*}{15} & Raw & $\begin{array}{c}7.39^{c} \\
( \pm 0.03) \\
\end{array}$ & $\begin{array}{c}4.51^{\mathrm{a}} \\
( \pm 0.07) \\
\end{array}$ & $\begin{array}{l}14.31^{\mathrm{C}} \\
( \pm 0.07)\end{array}$ & $\begin{array}{c}4.17^{\mathrm{a}} \\
( \pm 0.12) \\
\end{array}$ & $\begin{array}{c}4.09^{\mathrm{a}} \\
( \pm 0.09) \\
\end{array}$ & $\begin{array}{l}65.51^{\mathrm{e}} \\
( \pm 0.28) \\
\end{array}$ & $\begin{array}{l}1085.83^{f} \\
( \pm 0.61)\end{array}$ \\
\hline & Fermented & $\begin{array}{c}8.42^{\mathrm{a}} \\
( \pm 0.03)\end{array}$ & $\begin{array}{c}4.49^{\mathrm{a}} \\
( \pm 0.13)\end{array}$ & $\begin{array}{l}15.37^{\mathrm{a}} \\
( \pm 0.07)\end{array}$ & $\begin{array}{c}3.84^{\mathrm{b}} \\
( \pm 0.09)\end{array}$ & $\begin{array}{c}3.99^{\mathrm{a}} \\
( \pm 0.14)\end{array}$ & $\begin{array}{l}64.05^{f} \\
( \pm 0.22)\end{array}$ & $\begin{array}{l}1056.67^{g} \\
( \pm 0.75)\end{array}$ \\
\hline
\end{tabular}

*Means not sharing a common letter in the same column are significantly different $(\mathrm{p} \leq 0.05$

*Each value in the Table is a mean of three replicates \pm S.D. 


\section{International Journal of Science and Research (IJSR) \\ ISSN (Online): 2319-7064 \\ Index Copernicus Value (2013): 6.14 | Impact Factor (2014): 5.611}

As shown in Table 2. The moisture content of sorghum flour (Tabat cultivar) was $7.35 \%$. Supplementation of sorghum flour with 5, 10 and $15 \%$ of MLP significantly ( $\mathrm{P} \leq 0.05)$ increased the moisture content to $8.11,8.39$ and $7.39 \%$, respectively. Fermentation after 24 h significantly ( $\mathrm{P} \leq 0.05$ ) increased the moisture content of sorghum flour and composite flour supplemented with 5 and $10 \%$ MLP, whereas significant ( $\mathrm{P} \leq 0.05$ ) increase was observed of that flour supplemented with 15\% MLP.

The ash content of sorghum flour was found to be $1.31 \%$. Supplementation with 5\% MLP insignificantly ( $\mathrm{P} \geq 0.05$ ) increased the ash content to $1.86 \%$, while a significant( $\mathrm{P} \leq$ $0.05)$ increase was observed in ash content of that flours supplemented with 10 and 15\% MLP ( 3.36 and 4.51\% ), respectively. Fermentation of raw sorghum flour insignificantly $(\mathrm{P} \geq 0.05)$ increased the ash content from 1.32 to $1.43 \%$, while it was decreased insignificantly ( $\mathrm{P} \geq 0.05$ ) of those supplemented flour with 5, 10 and 15\% MLP to $1.76,2.49$ and $4.49 \%$, respectively.

This finding was agreed with that reported by Mohammed Nour (2013) who reported that the fermentation of supplemented flour with Moringa seeds cake / Fenugreek seeds flours decreased the ash content. The decrease in ash content after fermentation may be due to the utilization of ash by fermentation microorganisms.

The protein content of raw sorghum flour was found to be $10.31 \%$ and after supplementation with 5, 10 and 15\% MLP it was significantly ( $\mathrm{P} \leq 0.05$ ) increased to $11.87,12.89$ and $14.31 \%$, respectively. Fermentation of raw and supplemented flour with 5, 10 and 15\% MLP significantly ( $\mathrm{P} \leq 0.05$ ) increased the protein content to $12.38,13.32,14.83$ and 15.37, respectively . A similar trend was reported by Elhaj, (2009) who reported that fermentation for $36 \mathrm{~h}$ significant $(\mathrm{P} \leq 0.05$ ) increased the protein content of both sorghum flour sorghum flour supplemented with $20 \%$ defatted ground nut flour. This rise in protein content during fermentation might be due to the synthesis of protein by microorganisms (El Hidai, 1978).

The oil content of raw sorghum flour was found to be 2.85\%. Supplementation with 5\% MLP insignificantly ( $\mathrm{P} \geq$ 0.05 ) decreased the oil content to $2.65 \%$, whereas it was significantly ( $\mathrm{P} \leq 0.05$ ) increased after supplementation with 10 and $15 \%$ MLP to 3.75 and $4.17 \%$, respectively. Fermentation was decreased the oil content of raw sorghum flour and flour supplemented with 15\% MLP to 2.36 and $3.84 \%$, respectively, while the oil content flours supplemented with 5 and 10\% MLP insignificantly ( P $\geq$ 0.05 ) increased of oil content to 2.81 and $3.68 \%$, respectively. The result agrees with that reported by Mohammed Nour , (2013) who reported that the oil content was fluctuated during fermentation of millet flour supplemented with Moringa seeds cake / fenugreek seeds flour. The increase in oil content during fermentation of composite flour could be due to the transformation of the carbohydrate to fat, while the decrease in oil content of raw sorghum flour during fermentation may be due to the transformation of some of the oil, which possibly used by microorganisms as a carbon source to some other metabolites Lehninger, 1987). Akindumila and Glatz (1998) reported that certain fungi can reduce microbial oil during fermentation. Fiber content of sorghum flour was found to be $2.43 \%$.Supplementation of sorghum flour with 10 and $15 \%$ MLP significantly ( $\mathrm{P} \leq 0.05$ ) increased the fiber content to 3.19 and $4.09 \%$, respectively, while insignificant ( $\mathrm{P} \geq 0.05$ ) increase was observed after supplementation with $5 \%$ MLP.

The increase in fiber content of supplemented flour may be due to high content of fiber in Moringa leaves flour. Fermentation of raw sorghum flour and flours supplemented with 5, 10 and $15 \%$ insignificantly ( $P \geq 0.05$ ) decreased the fiber content to 2.40, 2.63, 3.15 and $3.99 \%$, respectively. This study disagrees with that reported by Mohammed Nour , (2013) who reported that fermentation increased the fiber content of millet flour and composite flour supplemented with Moringa seeds cake flour. The decrease in fiber content after fermentation of raw and composite flour may attribute to utilization of fiber by microorganisms. The carbohydrate content of sorghum flour observed to be $75.74 \%$. Supplementation with 5, 10 and 15\% ML significantly ( $\mathrm{P} \leq$ 0.05 ) decreased the carbohydrate content to 72.54, 86.41, $65.51 \%$,respectively. The substantially lower carbohydrate content of MLP sorghum composite flour was a result of low carbohydrate content in Moringa leaves. Similarly, it has been reported that compositing marama been flour with sorghum meal significantly reduced the carbohydrate content, Kayites et al ,(2010). Fermentation of raw sorghum flour and flour supplemented with 5, 10 and 15\% MLP slightly decreased the carbohydrate content to 75.21, 72.53, 67.39 and $64.05 \%$, respectively. A similar findings was reported by Mohammed Nour ,(2013) who reported that the carbohydrate was reduced during fermentation of millet flour and millet flour fortified with Moringa or fenugreek seeds flours. The reduction in carbohydrate during fermentation may be due to the utilization of sugars as energy source by microorganisms or converted to alcohol by lactic acid bacteria. The total energy of sorghum flour was found to be $369.86 \mathrm{kcal}$. Supplementation of sorghum flour with 5\% MLP significantly $(\mathrm{P} \leq 0.05)$ decreased the total energy to $358.99 \mathrm{kcal}$, while supplementation with 10 and $15 \%$ MLP significantly $(\mathrm{P} \leq 0.05)$ increased the total energy to 371.37 and $1085.09 \mathrm{kcal}$, respectively. The reduction in total energy may attributed to the reduction in carbohydrate and oil of 5\% composite flour, whereas the increase in total energy of 10 and 15\% MLP composite flour may be as the result of increase carbohydrate content and higher content of oil . A similar observation on the reduction of energy due to supplementation of sorghum / wheat flours with defatted soy flour has recently been reported by Serrem et al, (2011). Fermentation of raw sorghum flour and composite flours supplemented with 5, 10 and 15\% MLP significantly (P $\leq$ 0.05 ) decreased the total energy to $364.49,356.99,370.09$ and $1056.67 \mathrm{kcal}$, respectively.

Table 3: Minerals composition (mg/100g) of sorghum (Tabat) and Moringa Leaves Powder (MLP)

\begin{tabular}{|l|c|c|c|c|}
\hline \multicolumn{1}{|c|}{ Samples } & $\mathrm{Ca}$ & $\mathrm{K}$ & $\mathrm{Mg}$ & $\mathrm{Fe}$ \\
\hline Moringa leaves & 36.49 & 434.60 & 233.50 & 9.18 \\
\hline Sorghum & 0.85 & 181.70 & 263.50 & 0.07 \\
\hline
\end{tabular}

*Each value in the Table is a mean of three replicates \pm S.D 


\section{International Journal of Science and Research (IJSR) ISSN (Online): 2319-7064 \\ Index Copernicus Value (2013): 6.14 | Impact Factor (2014): 5.611}

The minerals content of raw sorghum flour and MLP are shown in Table 3 . The $\mathrm{Ca}, \mathrm{K}$ and Fe content of MLP were found to be 36.49, 434.60, 233.50 and $9.18 \mathrm{mg} / 100 \mathrm{~g}$, respectively, These values were lower than that obtained by Sodamade et al .,(2013) who gave $723.00,677.00$ and $187.00 \mathrm{mg} / 100 \mathrm{~g}$ for $\mathrm{Ca}, \mathrm{Mg}$ and $\mathrm{Fe}$, respectively except the $\mathrm{K}$ content was significantly higher, who reported 23.20 $\mathrm{mg} / 100 \mathrm{~g}$ for $\mathrm{K}$. The $\mathrm{Ca}, \mathrm{K}, \mathrm{Mg}$ and Fe were found to be 0.85 , 181.70, 263.50 and $0.07 \mathrm{mg} / 100 \mathrm{~g}$, respectively, which were lower except $\mathrm{Mg}$ content than those reported by Idris et al., (2005) who reported that the values of $\mathrm{Ca}, \mathrm{K}, \mathrm{Mg}$ and $\mathrm{Fe}$ contents of sorghum flour were 10.8, 450, 59.3 and $3.8 \mathrm{mg} / 100 \mathrm{~g}$, respectively. The variation in minerals contents of MLP and sorghum flour may be attributing to the genotypes and environmental conditions.

As shown in table 4, the Ca content of sorghum flour was found to be $0.85 \mathrm{mg} / 100$. Supplementation of sorghum flour with 5 and $10 \%$ MLP insignificant $(\mathrm{P} \geq 0.05)$ increased the Ca content to 2.84 and $3.86 \mathrm{mg} / 100 \mathrm{~g}$, respectively, whereas supplementation with $15 \%$ MLP significantly $(\mathrm{P} \leq 0.05)$ increased the Ca content to $5.63 \mathrm{mg} / 100 \mathrm{~g}$. The improvement of $\mathrm{Ca}$ after supplementation due to the high content of $\mathrm{Ca}$ content in Moringa leaves. Fermentation of raw sorghum flour and supplemented flour with 5\% MLP insignificantly ( $\mathrm{P} \geq 0.05$ ) increased $\mathrm{Ca}$ content to 1.32 and $3.39 \mathrm{mg} / 100 \mathrm{~g}$, while the fermentation of composite flours supplemented with 10 and $15 \%$ MLP significantly( $P \leq 0.05)$ increased the Ca content to 5.52 and $10.08 \mathrm{mg} / 100 \mathrm{~g}$. The results obtained were comparable with that reported by Mohammed Nour , (2013) who reported that the supplementation of millet flour with Moringa cake flour / Fenugreek seeds flour and fermentation improved the Ca content. The improvement of total Ca content of fermented flour may be to the reduction of phytic acid content.

Table 4: Effect of fermentation on Total (mg /100g) minerals of Sorghum flour supplemented with difference ratios of Moringa leaves

\begin{tabular}{|c|c|c|c|c|c|}
\hline \\
\hline Supplementation level (\%) & Treatment & $\mathrm{Ca}$ & K & $\mathrm{Mg}$ & $\mathrm{Fe}$ \\
\hline \multirow[t]{2}{*}{0} & Raw & $\begin{array}{c}0.85^{\mathrm{d}} \\
( \pm 0.02)\end{array}$ & $\begin{array}{c}181.7^{\mathrm{a}} \\
( \pm 28.16)\end{array}$ & $\begin{array}{c}50.00^{\mathrm{a}} \\
( \pm 1.23)\end{array}$ & $\begin{array}{l}1.07^{\mathrm{a}} \\
( \pm .02)\end{array}$ \\
\hline & Fermented & $\begin{array}{c}1.32^{\mathrm{d}} \\
( \pm 0.04)\end{array}$ & $\begin{array}{c}177.2^{\mathrm{a}} \\
( \pm 1.84)\end{array}$ & $\begin{array}{l}86.00^{b} \\
( \pm .41)\end{array}$ & $\begin{array}{c}2.03^{\mathrm{b}} \\
( \pm .01)\end{array}$ \\
\hline \multirow[t]{2}{*}{$5 \%$} & Raw & $\begin{array}{c}2.84^{\mathrm{C}} \\
( \pm 0.61) \\
\end{array}$ & $\begin{array}{c}199.5^{\mathrm{b}} \\
( \pm 3.27)\end{array}$ & $\begin{array}{c}61.50^{\mathrm{C}} \\
( \pm 2.12) \\
\end{array}$ & $\begin{array}{c}1.93^{\mathrm{b}} \\
( \pm .07)\end{array}$ \\
\hline & Fermented & $\begin{array}{c}3.39^{\mathrm{c}} \\
( \pm 0.07)\end{array}$ & $\begin{array}{c}211.8^{\mathrm{C}} \\
( \pm 2.46)\end{array}$ & $\begin{array}{c}120.00^{\mathrm{d}} \\
( \pm .48)\end{array}$ & $\begin{array}{l}2.76^{\mathrm{C}} \\
( \pm .08)\end{array}$ \\
\hline \multirow[t]{2}{*}{$10 \%$} & Raw & $\begin{array}{c}3.86^{\mathrm{c}} \\
( \pm 0.03) \\
\end{array}$ & $\begin{array}{l}211.89^{c} \\
( \pm 23.33) \\
\end{array}$ & $\begin{array}{c}126.00^{\mathrm{e}} \\
( \pm .01) \\
\end{array}$ & $\begin{array}{l}2.63^{\mathrm{c}} \\
( \pm .05) \\
\end{array}$ \\
\hline & Fermented & $\begin{array}{c}5.52^{\mathrm{b}} \\
( \pm 0.43)\end{array}$ & $\begin{array}{l}227.00^{d} \\
( \pm 2.12)\end{array}$ & $\begin{array}{l}188.83^{\mathrm{f}} \\
( \pm 0.75)\end{array}$ & $\begin{array}{l}3.55^{\mathrm{d}} \\
( \pm .03\end{array}$ \\
\hline \multirow[t]{2}{*}{$15 \%$} & Raw & $\begin{array}{c}5.63^{\mathrm{b}} \\
( \pm 0.44) \\
\end{array}$ & $\begin{array}{c}271.83^{\mathrm{e}} \\
( \pm 2.46 \\
\end{array}$ & $\begin{array}{l}263.50^{\mathrm{g}} \\
( \pm 0.36)\end{array}$ & $\begin{array}{c}2.94^{\mathrm{C}} \\
( \pm .05) \\
\end{array}$ \\
\hline & Fermented & $\begin{array}{c}10.08^{\mathrm{a}} \\
( \pm 0.35)\end{array}$ & $\begin{array}{l}237.00^{\mathrm{f}} \\
( \pm 8.73)\end{array}$ & $\begin{array}{c}2.92^{\mathrm{h}} \\
( \pm 46.01)\end{array}$ & $\begin{array}{c}5.04^{\mathrm{e}} \\
( \pm .05)\end{array}$ \\
\hline
\end{tabular}

*Means not sharing a common letter in the same column are significantly different $(\mathrm{p} \leq 0.05$

*Each value in the Table is a mean of three replicates \pm S.D

The $\mathrm{K}$ content of sorghum flour was found to be $181.7 \mathrm{mg} / 100 \mathrm{~g}$. Supplementation of raw sorghum flour with 5, 10 and 15\% MLP significantly $(\mathrm{P} \leq 0.05)$ increased the $\mathrm{K}$ content to 1.99 .5 , 211.89 and $271.83 \mathrm{mg} / 100 \mathrm{~g}$, respectively. The improvement of $\mathrm{K}$ after supplementation due to the high content of $\mathrm{K}$ content in Moringa leaves. Fermentation of sorghum flour insignificantly $(\mathrm{P} \geq 0.05)$ increased the $\mathrm{K}$ content to $177.2 \mathrm{mg} / 100 \mathrm{~g}$, while a significant $(\mathrm{P} \leq 0.05)$ increase was observed after fermentation of supplemented flour with 5, 10 and 15\% MLP to 211.8, 227.00 and $237.00 \mathrm{mg} / 100$, respectively. The improvement of total $\mathrm{K}$ content of fermented flour may be to the reduction of phytic acid content. Mg content of sorghum flour was found to be $50.00 \mathrm{mg} / 100 \mathrm{~g}$.

Supplementation of sorghum flour with 5,10 and 15\% MLP significantly( $\mathrm{P} \leq 0.05)$ increased the Mg content to 61.50 , 126.00 and $263.50 \mathrm{mg} / 100 \mathrm{~g}$, respectively. The improvement of $\mathrm{Mg}$ content after supplementation due to the high content of $\mathrm{Mg}$ in Moringa leaves fermentation of sorghum flour and composite flours supplemented with 5, 10 and 15\% MLP significantly $(\mathrm{P} \leq 0.05)$ increased the $\mathrm{Mg}$ content to 86.00 , $120.00,188.83$ and $2.92 \mathrm{mg} / 100 \mathrm{~g}$, respectively. The improvement of total $\mathrm{Mg}$ content of fermented flour may be to the reduction of phytic acid content.

The Fe content of sorghum flour was $1.07 \mathrm{mg} / 100 \mathrm{~g}$.Supplementation of sorghum flour with 5,10 and $15 \%$ MLP significantly $(\mathrm{P} \leq 0.05)$ increased the Fe content to $1.93,2.63$ and $2.94 \mathrm{mg} / 100 \mathrm{~g}$, respectively. The improvement of Fe content after supplementation due to the high content of $\mathrm{Fe}$ in Moringa leaves. Fermentation of sorghum flour and composite flour supplemented with 5, 10 and $15 \%$ MLP significantly $(\mathrm{P} \leq 0.05)$ increased the $\mathrm{Fe}$ content to 2.03, 2.76, 3.55 and $5.04 \mathrm{mg} / 100 \mathrm{~g}$, respectively. A similar study was obtained by Mohammed Nour, (2013), who reported that the supplementation with Moringa Seeds cake and fermentation improved the total and extractable Fe. The improvement of total Fe content of fermented flour may be to the reduction of phytic acid content. 


\section{International Journal of Science and Research (IJSR) \\ ISSN (Online): 2319-7064 \\ Index Copernicus Value (2013): 6.14 | Impact Factor (2014): 5.611}

Table 5: Sensory evaluation of thick porridge (aceda) made from sorghum flour supplemented with different ratios of Moringa leaves

\begin{tabular}{|c|c|c|c|c|c|}
\hline Supplementation level (\%) & Colour & Taste & Flavour & Texture & General acceptability \\
\hline 0 & $\begin{array}{c}4.30^{\mathrm{a}} \\
( \pm 0.87)\end{array}$ & $\begin{array}{c}4.00^{\mathrm{a}} \\
( \pm 1.26)\end{array}$ & $\begin{array}{l}3.80^{\mathrm{a}} \\
( \pm .98)\end{array}$ & $\begin{array}{c}3.30^{\mathrm{a}} \\
( \pm 1.27)\end{array}$ & $\begin{array}{c}3.48^{\mathrm{a}} \\
( \pm 0.83)\end{array}$ \\
\hline 5 & $\begin{array}{l}3.50^{\mathrm{b}} \\
( \pm 0.5)\end{array}$ & $\begin{array}{l}2.40^{\mathrm{b}} \\
( \pm 1.4)\end{array}$ & $\begin{array}{c}2.70^{\mathrm{b}} \\
( \pm 1.59)\end{array}$ & $\begin{array}{c}2.80^{\mathrm{b}} \\
( \pm 1.08)\end{array}$ & $\begin{array}{c}2.73^{\mathrm{b}} \\
( \pm 2.58)\end{array}$ \\
\hline 10 & $\begin{array}{c}2.70^{\mathrm{C}} \\
( \pm 1.27)\end{array}$ & $\begin{array}{l}2.60^{\mathrm{b}} \\
( \pm 1.4)\end{array}$ & $\begin{array}{c}2.80^{\mathrm{c}} \\
( \pm 1.31)\end{array}$ & $\begin{array}{l}2.90^{\mathrm{b}} \\
( \pm 1.4)\end{array}$ & $\begin{array}{c}2.88^{\mathrm{b}} \\
( \pm 1.17)\end{array}$ \\
\hline 15 & $\begin{array}{c}2.90^{\mathrm{d}} \\
( \pm 0.83)\end{array}$ & $\begin{array}{c}2.30^{\mathrm{b}} \\
( \pm 1.19)\end{array}$ & $\begin{array}{c}3.20^{\mathrm{d}} \\
( \pm 1,35)\end{array}$ & $\begin{array}{l}3.40^{\mathrm{a}} \\
( \pm .51)\end{array}$ & $\begin{array}{c}3.13^{\mathrm{a}} \\
( \pm 1.36)\end{array}$ \\
\hline
\end{tabular}

*Means not sharing a common letter in the same column are significantly different $(\mathrm{p} \leq 0.05$

*Each value in the Table is a mean of three replicates \pm S.D

The sensory evaluation of thick porridge (Aceda) of sorghum flour and composite flour supplemented with 5, 10 and 15\% Moringa Leaves Powder (MLP) was carried out and data was presented in Table 5. Analysis of variance showed significant difference ( $\mathrm{P} \leq 0.05$ ) between thick porridge made from sorghum flour (control) and thick porridge made from raw sorghum flour and composite sorghum flours supplemented with 5, 10 and 15\% MLP in terms of colour, taste, flavor, texture and general acceptability, but insignificant ( $\mathrm{P} \geq 0.05$ ) variation was observed in terms of texture and overall acceptability between the porridges of sorghum flour (control) and composite flour supplemented with 15\% MLP According to the performance of panelists, the majority gave the sensory performance for the colour to thick porridge of raw sorghum flour followed by that flours supplemented with 5, 15 and $10 \%$ MLP, respectively. Moreover high sensory performance for taste ,flavor and over all acceptability were also recorded for thick porridge of raw sorghum flour, while the thick porridge of composite flour supplemented with 5\% MLP recorded poor taste, flavor and over all acceptability. This may be due to the bitter taste and flavor of Moringa leaves. No significance differences( $P \geq 0.05$ ) was observed in texture values of thick porridge made from raw sorghum flour and composite flour supplemented with 15\%MLP and also between composite flour supplemented with 5 and $10 \%$ MLP, which a high texture score reported for that flour supplemented with 15\% MLP while the lowest texture score obtained for 5\% MLP supplemented flour . Regarding over all acceptability, the thick porridge of raw sorghum flour had a highest score, while that supplemented with 5\% MLP had the lowest score. The higher level of MLP fortification affected the sensory characteristics of the product. This may be attributed to unacceptable flavor and taste imposed by MLP.

\section{Conclusion}

Supplementation of sorghum flour with Moringa Leaves Powder (MLP) improved the nutritive value of sorghum flour quantitatively; fermentation of raw sorghum flour and composite flour had improved the minerals contents except the $\mathrm{K}$ content of raw sorghum flour it was slightly decreased after fermentation. Proximate composition of both raw sorghum and composite flours were fluctuated during supplementation with MLP and fermentation.

\section{References}

[1] Akindumila, F., \& Glatz, B.A. (1998). Growth and oil production of Apiotrichum curvatum in tomato juice . Journal of Food Production, 61(11), 1515-1517.

[2] AOAC (1990). Official Methods of Analysis. 15thedn. Washington, DC: Association of Official Analytical Chemists.

[3] Bolaji, S.A and Adeboye, O.O. (2013). Proximate Analysis , Minerals Contents and Functional properties of Moringa Oleifera Protein Concentrates. Journal of Applied Chemistry (IOSR-J AC), 4, 47-51.

[4] El Hidia, M.M. (1978). Biochemical and microbial investigation of kisra fermentation. M.Sc. Thesis, Faculty of Agriculture, University of Khartoum, Sudan.

[5] Elhaj, M.E.(2009). Protein quality and acceptability of sorghum flour supplemented with defatted groundnut flour as influenced by traditional processing. Ph.D. Thesis, Faculty of Agriculture, University of Khartoum, Sudan.

[6] El-Tinay, A.H., EL-Mahdi, Z.M. and El soubki, A. (1985). Supplementation of Fermented sorghum Kisra breadwith legume protein isolates. Journal of Food Technology, 20: 679-687.

[7] Fahey, J. W. 2005.Moringa oleifera: A Review of the Medical Evidence for Its Nutritional, Therapeutic, and Prophylactic Properties. Part 1. Trees for Life.

[8] Fugile, L. J. ((1999). The Miracle Tree: Moringa oleifera: Natural Nutrition for the Tropics. Church World Service, Dakar. 68 pp.; revised in 2001 and published as The Miracle Tree: The Multiple Attributes of Moringa, $172 \mathrm{pp}$.

[9] Idris WH, AbdelRahman SM, Elmaki HB, Babiker EE, EL Tinay AH.(2005) Effect of Germination, Fermentation and Cooking on Phytic Acid and Tannin Contents and Hcl-extractability of Minerals of Sorghum ( Sorghum bicolor ) Cultivars. J of Food and Technology 3(3) : 410-416

[10] Jirapa.P., Normah, H., Zamaliah, M.M., Asmah.R\&Mohamad ,K(2001). Nutritional quality of germinated cowpeaflour ( Vignaunguiculata) and its application in home preparing weaning foods . plant foods for humanNutrition . 56, 203-216.

[11] Kayitesi E, de Kock HL, Minnaar A, Duodu KG (2010) Nutritional quality and antioxidant activity of marama-sorghum composite flours and porridges. Food Chem 131: 837-842. 
[12] Lehninger, A.L. (1987). Bioenergetics and metabolism, principle of biochemistry ( $2^{\text {nd }}$ preprint). CBS.

[13] Minstry of Agriculture (1995). Department of Planning and Agriculture Policy; Khartoum, Sudan.

[14] Mohamed Nour, A.A. (2013). Chemical and Nutritional quality of millet flour supplemented with Moringa or Fenugreek seeds flour, Ph.D. thesis Omdurman Islamic University, Sudan.

[15] N Y Yonkers; Consumer report on Health. Consumer union of U.S.1988, Inc. Pp. 10703- 10705.

[16] Olugbemi, T.S, - Mutayoba, S.K. and Lekule, F.P. (2010). Effect of Moringa (Moringa oleifera) Inclusion in Cassava based diets to broiler chickens. In InternationalJournal of Poultry Science, vol. 9, No. 4, p. 363-367.

[17] Onwueme, I.C. and Sinha, T. D. (1991). Field crop production in tropical Africa principles and practice. TechnicalCenter for Agriculture Rural Co-operation.

[18] Pearson, D. (1981). Chemical Analysis of Food. Edn. Published by Egon, H; Kirk, R.S and Sawyer, New York. Peterson, R. G. (1985). Design and analysis of experiments. March Dekker Inc., New York, PP: 429.

[19] Ralph, D.; Wanisk and Rooney, L. W. (2000). Structure and chemistry of the sorghum caryopsis. Ch. 4 In:Sorghum Origin, Histroy Technology and Production. (C.W. Smith, R.A. Frederiksen eds.). Texas anduniversity . John Wiley and Sons. Inc.

[20] S M Islam ; M Yashimoto; A Yaharas ; S Okano; K Ishiguro; O Yamakawa.. Agric Food Chem., 2002, Vol. 50 American chemical society pp.3718-3722.

[21] Serrem CA, de Kock HL, Taylor JRN (2011). Nutritional quality, sensory quality and consumer acceptability of sorghum and bread wheat biscuits fortified with defatted soy flour. Inter J Food Sci Tech, 46: 74-83.

[22] Southgate, D.A. (1976). The Analysis of Dietary Fiber, in . G.A. Spiller and R. J. Amen (eds). Fiber in HumanNutrition. Plenur Press. New York, U.S.A, pp. 73.

[23] Sukker, M. Y., (1985). Human Nutrition for Medical studies and Applied Health Science. Ith(ed.). Thaca, Press13 South work street. London. 